\title{
Pengujian Toleransi Genotipe Padi (Oryza sativa L) terhadap Salinitas pada Stadia Perkecambahan
}

\section{Testing of Salinity Tolerance for Rice (Oryza sativa L.) Genotype at Germination Stage}

\author{
Donny Arzie, Abdul Qadir* dan Faiza C. Suwarno
}

\author{
Departemen Agronomi dan Hortikultura, Fakultas Pertanian, Institut Pertanian Bogor \\ (Bogor Agricultural University), J1. Meranti, Kampus IPB Darmaga, Bogor 16680, Indonesia \\ Telp.\&Faks. 62-251-8629353 e-mail agronipb@indo.net.id \\ *Penulis untuk korespondensi : abdulqadir_benih@yahoo.co.id
}

Disetujui 14 November 2015 /Published online 12 Desember 2015

\begin{abstract}
The objective of the research was to find out a simple, fast and inexpensive method for testing salt tolerant of rice genotypes at germination stage. The experiment was conducted at the Laboratory of Seed Science and Technology, Bogor Agricultural University and the Experimental Station of Rice Research at Muara, Bogor from june 2010 until january 2011. Germinating seed on strawpaper in UKDdp method with 4000 ppm NaCl for 2 weeks was the best method for differentiating the tolerant varieties from the susceptible at the laboratory condition. The method is easily applicated, takes a short times and efficient in space. A total 40 rice genotypes were then tested for salinity tolerance by the method and standard method. In the standard method, two week old seedling were transplanted to soil medium salinized with $4000 \mathrm{ppm} \mathrm{NaCl} \mathrm{for}$ 6 weeks at the greenhouse. Dead leaf percentage variable could differentiate 7 toleran rice genotypes, 19 moderately tolerant genotypes, 14 moderately susceptible genotypes, and 4 susceptible. Lalan was the most tolerant genotype to salin condition, followed consecutively by B11844-MR-23-4-6, B13133-9-MR-3-KY-2, and B13136-3-MR-1-KY-5. Low correlation coefficient between salinity tolerance variable in the laboratory and in the greenhouse, might be caused by different growth stage.
\end{abstract}

Key words : Genotype of rice, salinity tolerance, germination stage

\section{ABSTRAK}

Tujuan dari penelitian ini adalah untuk mengetahui metode yang sederhana, cepat dan murah untuk menguji toleran garam dari genotipe padi pada tahap perkecambahan. Penelitian dilakukan di Laboratorium Ilmu dan Teknologi Benih, Institut Pertanian Bogor dan Stasiun Percobaan Rice Research di Muara, Bogor pada Juni 2010 sampai Januari 2011. Berkecambah benih dilakukan di atas kertas merang dengan metode UKDdp menggunakan 4000 ppm NaCl selama 2 minggu adalah metode terbaik untuk membedakan varietas toleran dan rentan pada kondisi laboratorium. Metode ini mudah diaplikasikan, membutuhkan waktu yang singkat dan efisien dalam ruang. Sebanyak 40 genotipe padi kemudian diuji untuk toleransi salinitas dengan metode ini dan metode standar. Dalam metode standar, bibit berumur dua minggu ditransplantasikan ke media tanah salin dengan 4000 ppm NaCl selama 6 minggu di rumah kaca. Variabel persentase daun mati dapat untuk membedakan 7 genotipe padi toleran, 19 genotipe agak toleran, 14 genotipe agak rentan, dan 4 rentan. Lalan adalah genotipe yang paling rentan terhadap kondisi salin, diikuti oleh B11844-MR-23-4-6, B13133-9-MR-3-KY-2, dan B13136-3-MR-1-KY-5. Koefisien korelasi yang rendah antara variabel toleransi salinitas di laboratorium dan di rumah kaca, mungkin disebabkan oleh tahap pertumbuhan yang berbeda.

Kata Kunci: genotipe padi, tahapan perkecambahan, toleransi salinitas 


\section{PENDAHULUAN}

Indonesia diperkirakan memiliki 40-43 juta hektar lahan bermasalah dan 13.2 juta ha dari lahan itu terpengaruh salinitas. Lahan-lahan itu pada umumnya lahan pantai, muara sungai, dan delta yang dipengaruhi oleh intrusi air laut (DPU, 1997). Masalah salinitas menjadi salah satu faktor pembatas dalam meningkatkan produktivitas, sehingga dilakukan pengujian ketahanan berbagai varietas padi terhadap tingkat salinitas sebelum dilakukan penanaman ke lapang dan dengan menciptakan varietas yang toleran terhadap salinitas serta mencari alternatif toknologi metode uji toleransi padi yang cepat, tepat dan mudah.

Analisis terhadap tingkat toleransi tanaman pada cekaman salinitas dapat dilakukan dengan menciptakan media tumbuh yang dapat menjabarkan kondisi salin seperti penggunaan larutan garam. Suatu pengujian untuk melihat tingkat toleransi terhadap salinitas dapat dilakukan diberbagai media tumbuh yang sederhana seperti pasir, kertas dan jenis media tanam lainnya. Sadjad (1993) menyatakan bahwa substrat kertas merang yang dicelup dalam larutan garam $\mathrm{NaCl}$ dapat digunakan untuk menciptakan tekanan osmose yang tinggi dan selama tidak memberikan efek peracunan substrat.

Pengujian benih padi pada fase perkecambahan sangat penting dan merupakan metode seleksi yang sangat cepat dan efisien dalam menentukan tingkat toleransi suatu genotipe terhadap salinitas. Melalui pengujian tingkat toleransi pada fase awal pertumbuhan bibit padi, diharapkan mampu menghasilkan suatu metode yang lebih cepat dan tepat dalam menentukan suatu genotipe toleran. Tujuan dari penelitian ini yaitu memperoleh metode yang lebih cepat dan mudah dalam menyeleksi genotipe padi toleran salinitas pada stadia awal pertumbuhan dan menyeleksi genotipe-genotipe padi yang toleran terhadap salinitas.

\section{METODE PENELITIAN}

Percobaan dilakukan di laboratorium dan di rumah kaca. Percobaan di laboratorim terdiri dari 3 tahap yaitu : (1) Uji pendahuluan untuk mendapatkan lima metode yang berpotensi dalam pengujian toleransi salinitas padi, (2) Pemilihan satu metode uji terbaik diantara lima metode berpotensi dari media kertas dan media padat, (3) Pengujian toleransi terhadap salinitas 40 genotipe padi pada satu metode uji yang terpilih.

Uji Pendahuluan. Uji pendahuluan bertujuan mencari komposisi media dan konsentrasi garam $\mathrm{NaCl}$ yang dapat membedakan pertumbuhan varietas padi yang toleran dan peka. Konsentrasi $\mathrm{NaCl}$ yang digunakan terdiri dari 9 tingkat konsentrasi yaitu 0, 3000, 4000, 5000, $6000,7000,8000,9000,10.000$ ppm untuk seluruh media. Media yang digunakan dari media padat yaitu arang sekam, cocopeat, humus daun bambu, arang sekam + cocopeat, arang sekam + humus daun bambu dan cocopeat + humus daun bambu serta media kertas merang. ulangan dalam percobaan ini dilakukan sebanyak 3 kali, sehingga pada media padat terdiri dari 162 satuan percobaan sedangkan media kertas merang terdiri dari 27 satuan percobaan. Pengujian dianalisis menggunakan uji $\mathrm{t}$ dan berdasarkan hasil selisih antara varietas toleran dan varietas peka, hasil analisis digunakan untuk mendapatkan lima metode terbaik yang berpotensi membedakan varietas toleran dan peka. Analisis antara media kertas dan padat dilakukan secara terpisah.

Pemilihan satu metode uji terbaik diantara lima metode berpotensi dari media kertas dan media padat. Percobaan (2) dilakukan dengan menggunakan model Rancangan Kelompok Lengkap Teracak (RKLT) faktorial dua faktor. Faktor pertama adalah metode uji (media dan konsentrasi $\mathrm{NaCl}$ ) dan faktor kedua adalah varietas. Data yang berpengaruh nyata pada analisis ragam akan dilanjutkan dengan uji Duncan Multiple Range Test (DMRT). Setiap ulangan ditanam sebanyak 10 butir benih padi pada setiap varietas. Pengujian ini dilakukan 3 kali ulangan. Benih padi ditanam hingga berumur 2 minggu. Penentuan satu metode terbaik dari lima metode berpotensi media kertas dan padat menggunakan hasil selisih antara varietas toleran dan varietas peka yang digunakan. Kemudahan dalam aplikasi, efisiensi tempat pengujian dan waktu pengamatan, kemampuan memberikan kemudahan untuk menilai struktur pertumbuhan secara jelas juga menjadi pertimbangan dalam memilih satu metode terbaik. Berdasarkan pengujian (2), satu metode terbaik adalah menggunakan media kertas merang dengan konsentrasi 4000 ppm.

$$
\text { Pengujian } 40 \text { genotip padi pada satu }
$$
metode uji yang terpilih. Pengujian (3) menyeleksi genotipe padi yang toleran dan peka terhadap salinitas dengan menggunakan satu metode uji yang terbaik dari hasil pengujian (2). Pengujian dilakukan terhadap genotipe padi yang belum diketahui sifat toleran dan pekanya. Benih padi ditanam pada media kertas merang 4000 ppm $\mathrm{NaCl}$ hingga berumur 2 minggu. Rancangan percobaan yang digunakan adalah RKLT dengan satu faktor yaitu genotipe padi. Genotipe padi yang digunakan sebanyak 40 genotipe dan setiap satuan percobaan diulang empat kali. 
Pengujian toleransi salinitas padi di rumah kaca. Pengujian di Rumah Kaca bertujuan untuk mengetahui toleransi salinitas 40 genotipe padi melalui metode standar di rumah kaca, serta untuk melihat korelasi dengan pengujian di laboratorium. Rancangan percobaan menggunakan RKLT dengan satu faktor yaitu genotipe padi. Pokali dan Lalan sebagai cek varietas toleran dan IR64 dan Ciherang sebagai varietas peka diikutkan dalam penanaman. Data pengujian antara peubah yang diamati di laboratorium dikorelasikan dengan data persentase daun mati di rumahn kaca. Pengelompokan genotipe padi pada pengujian di rumah kaca dilakukan berdasarkan persentase daun mati dimana tanaman yang memiliki persentase daun mati $>0-\leq 50$ (toleran), $>50-\leq 70$ (Agak Toleran), $>70-\leq 90$ (agak peka), dan $>90-\leq$ 100 (peka) (IRRI dalam Sulaiman, 1980).

\section{Pelaksanaan}

Penanaman uji pendahuluan pada media kertas menggunakan teknik Uji Kertas Digulung dengan Plastik (UKDdp) dan didirikan, teknik ini menggunakan 3 lembar kertas yang telah direndam dengan larutan $\mathrm{NaCl}$ dan di press serta selembar plastik pada dasarnya agar tidak tembus akar dan menjaga kelembaban. Kertas merang dilipat menjadi dua sejajar penjangnya dan diatas media ditanam 15 butir benih padi tiap varietas, media setengahnya ditutupkan, kemudian digulung. Varietas padi toleran dan peka yang ditanam pada metode media padat, masing-masing berjumlah 5 butir dalam satu wadah. Wadah yang digunakan pada metode media padat di uji pendahuluan menggunakan wadah sterofoam dengan diameter $12.5 \mathrm{~cm}$ dan tinggi $6.5 \mathrm{~cm}$, media tanam disiram dan diaduk sampai merata dengan larutan $\mathrm{NaCl}$. Benih yang digunakan direndam selama \pm 5 menit untuk menyeleksi padi yang hampa dan tidak. Pengamatan dilakukan dengan mengukur tinggi tajuk kecambah. Perlakuan yang berpotensi memperlihatkan perbedaan antara genotipe toleran dan peka akan digunakan pada tahap pengujian (2).

Varietas yang digunakan pada pengujian (2) ditanam 10 butir benih tiap varietas. Wadah penanaman pada media padat menggunakan plastik mika berukuran $22.5 \mathrm{~cm}$ x $14 \mathrm{~cm} \mathrm{x} 4 \mathrm{~cm}$, media tanam disiram dan diaduk sampai merata dengan larutan $\mathrm{NaCl}$ sesuai dengan perlakuan rekomendasi hasil pengujian pendahuluan. Pencampuran media menggunakan perbandingan $1: 1$, bobot total arang sekam + cocopeat sebesar $138 \mathrm{~g}$ dicampur dengan $400 \mathrm{ml}$ larutan $\mathrm{NaCl}$, bobot media tunggal cocopeat sebesar $135 \mathrm{~g}$ dan
$400 \mathrm{ml}$ larutan $\mathrm{NaCl}$ sedangkan bobot media tunggal arang sekam sebesar $140 \mathrm{~g}$ dan $350 \mathrm{ml}$ larutan $\mathrm{NaCl}$. Penanaman pada media kertas dilakukan dengan cara yang sama seperti uji pendahuluan. Penanaman dilakukan hingga berumur 2 MST.

Pengujian 40 genotipe menggunakan satu metode terpilih yaitu media kertas merang dengan konsentrasi $4000 \mathrm{ppm}$. Setiap satu gulungan media kertas ditanam satu jenis genotipe masingmasing sebanyak 15 butir dengan empat kali ulangan. Penanaman dan pengamatan dilakukan hingga umur 2 MST. Pelaksanaan penanaman menggunakan sistem UKDdp.

Percobaan di rumah kaca mengacu pada percobaan Sulaiman (1980), dengan menanam bibit padi pada bak plastik dengan ukuran $35 \mathrm{~cm} \mathrm{x}$ $30 \mathrm{~cm} \times 10 \mathrm{~cm}$ dan berisi tanah $5 \mathrm{~kg}$ kering angin per bak yang telah diberi 4 liter larutan garam berkonsentrasi $4000 \mathrm{ppm}$, setiap pot ditanam 3 genotipe masing-masing genotipe 2 bibit padi berumur 2 minggu dipersemaian. Bibit padi ditanam pada kondisi salin hingga berumur 6 MST. Pupuk Urea, $\mathrm{KCl}$ dan Sp18 ditambahkan pada awal penanaman.

\section{Pengamatan}

Pengamatan pada stadia perkecambahan di laboratorium. Pengamatan yang dilakukan pada percobaan pendahuluan adalah tinggi tajuk tanaman. Pengamatan yang dilakukan pada percobaan pengujian toleransi padi pada metode uji selanjutnya adalah : Panjang Akar, Tinggi Tajuk, Panjang Kecambah, Bobot Kering Akar, Bobot Kering Tajuk, Bobot Kering Kecambah.

Pengamatan pada percobaan di rumah kaca. Tinggi Tajuk, Panjang Akar, Panjang Tanaman, Bobot Kering Akar, Bobot Kering Tajuk, Bobot Kering Tanaman, Jumlah Daun, Persentase daun Mati.

\section{HASIL DAN PEMBAHASAN}

\section{Uji Pendahuluan Media Padat}

Hasil pengamatan terhadap tinggi tajuk dari 54 kombinasi media padat yang digunakan didapatkan lima metode yang memiliki nilai selisih rataan terbesar antara genotipe toleran dengan peka. Metode tersebut juga dipilih dari hasil uji t yang menunjukkan perbedaan nyata antara varietas toleran dan peka yang secara visual dilihat dari tinggi tajuk juga dapat memperlihatkan perbedaan antara kedua varietas (Tabel 1). 
Tabel 1. Hasil lima selisih terbesar tinggi tajuk dan Uji $t$ antara varietas peka dengan varietas toleran pada media padat

\begin{tabular}{ccrcccc}
\hline \multirow{2}{*}{$\mathrm{NaCl}(\mathrm{ppm})$} & Media & \multicolumn{3}{c}{$\begin{array}{c}\text { Rataan } \\
\text { Varietas }\end{array}$} & $\begin{array}{c}\text { Selisih } \\
\text { T-P }\end{array}$ & $\begin{array}{c}\text { Hasil } \\
\text { Uji-t }\end{array}$ \\
\cline { 3 - 4 } & & $\mathrm{T}$ & $\mathrm{P}$ & & 3.66 & $*$ \\
\hline 3000 & $\mathrm{C}$ & 10.45 & 6.79 & 3.52 & $*$ \\
4000 & $\mathrm{C}$ & 9.90 & 6.38 & 3.63 & $*$ \\
4000 & $\mathrm{ASC}$ & 10.55 & 6.92 & 3.86 & $*$ \\
5000 & ASC & 10.31 & 6.44 & 3.69 & $*$ \\
9000 & AS & 8.07 & 4.38 & & $*$ \\
\hline
\end{tabular}

Keterangan $: \mathrm{AS}=$ Arang sekam, ASC $=$ Arang sekam + cocopeat, $\mathrm{C}=$ Cocopeat, $\mathrm{P}=\mathrm{Varietas}$ Peka, $\mathrm{T}=\mathrm{Varietas}$ Toleran, $*=$ berbeda nyata pada uji $\mathrm{t}$ taraf $5 \%$, th = tidak berbeda nyata

Hasil dari ke lima metode media padat (Tabel 1), terlihat bahwa uji t memiliki nilai yang berbeda nyata antara varietas toleran dan varietas peka, hal ini membuktikan bahwa metode-metode tersebut mampu membedakan antara kedua kelompok varietas dimana varietas toleran ratarata memiliki tinggi tajuk yang lebih tinggi dibandingkan dengan varietas peka. Metode yang memiliki nilai selisih terbesar $(3,86)$ yaitu metode dengan media arang sekam + cocopeat dengan konsentrasi $\mathrm{NaCl} 5000 \mathrm{ppm}$.

\section{Uji Pendahuluan Media Kertas}

Uji pendahuluan dengan menggunakan kertas merang menghasilkan lima tingkat konsentrasi garam $\mathrm{NaCl}$ yang diambil dari hasil uji $t$ dan lima selisih rataan terbesar antara varietas toleran dan peka, kelima konsentrasi terpilih yaitu 4000 ppm, 5000 ppm, 6000 ppm, 7000 ppm dan $8000 \mathrm{ppm}$.

Tabel 2. Hasil selisih tinggi tajuk dan uji t antara varietas peka dengan varietas toleran pada media kertas

\begin{tabular}{ccccc}
\hline $\begin{array}{c}\mathrm{NaCl} \\
(\mathrm{ppm})\end{array}$ & $\begin{array}{c}\text { Rataan } \\
\text { Varietas P }\end{array}$ & $\begin{array}{c}\text { Rataan } \\
\text { Varietas T }\end{array}$ & $\begin{array}{c}\text { Selisih } \\
\mathrm{T}-\mathrm{P}\end{array}$ & $\begin{array}{c}\text { Hasil } \\
\text { Uji t }\end{array}$ \\
\hline 0 & 13.18 & 12.85 & -0.32 & tn \\
3000 & 11.59 & 12.08 & 0.50 & tn \\
4000 & 10.81 & 12.22 & 1.42 & $*$ \\
5000 & 10.79 & 11.58 & 0.79 & $*$ \\
6000 & 9.81 & 10.79 & 0.97 & $*$ \\
7000 & 9.21 & 10.26 & 1.05 & $*$ \\
8000 & 8.87 & 9.81 & 0.94 & $*$ \\
9000 & 8.57 & 9.12 & 0.55 & tn \\
10000 & 6.70 & 7.08 & 0.37 & tn \\
\hline
\end{tabular}

Keterangan : $\mathrm{T}=$ Varietas Toleran, $\mathrm{P}=$ Varietas Peka,$*=$ berbeda nyata pada uji $\mathrm{t}$ taraf $5 \%$, $\mathrm{tn}=$ tidak berbeda nyata

Tabel 2 menjelaskan bahwa lima selisih terbesar pada tinggi tajuk memiliki nilai yang berbeda nyata berdasarkan uji t, rataan tinggi tajuk pada varietas yang toleran lebih besar dibandingkan dengan varietas peka sehingga gejala salinitas terlihat bahwa varietas toleran lebih mampu beradaptasi dibandingkan dengan varietas peka. Secara umum uji pendahuluan menggunakan kertas merang ini terlihat bahwa semakin tinggi konsentrasi $\mathrm{NaCl}$, maka tinggi tajuk akan semakin rendah. Seleksi genotipe menggunakan media kertas memerlukan ruang yang sedikit bila dibandingkan dengan media padat.

Daniels dalam Pratama (2010) menyatakan bahwa pengaruh potensial osmotik menyebabkan pengurangan laju pertumbuhan tinggi tanaman, baik efek racun ion $\mathrm{Na}$ atau $\mathrm{Cl}$, maupun potensial osmotik dapat mempengaruhi pertumbuhan tinggi tanaman. Menurut Sinaga dalam Pratama (2010) tanaman mengalami kekurangan air akibat penurunan potensial air. Terjadinya kekurangan air pada daun akan menyebabkan sel-sel penjaga kehilangan 
turgornya, sehingga proses pertumbuhan tinggi tanaman menjadi terhambat.

Pemilihan Satu Metode Uji Terbaik diantara Lima Metode Berpotensi dari Media Kertas dan Media Padat
Media padat. Metode MP2 pada Tabel 3 memperlihatkan perbedaan antara varietas toleran dan peka dengan selisih rataannya lebih besar antara kedua kelompok varietas tersebut dibandingkan metode lainnya pada seluruh peubah bobot kering.

Tabel 3. Rekapitulasi data selisih antara varietas toleran dan peka pada masing-masing peubah yang diamati di laboratorium pada media padat

\begin{tabular}{cccccc}
\hline \multirow{2}{*}{ Peubah } & \multicolumn{5}{c}{ Selisih } \\
\cline { 2 - 6 } & MP1 & MP2 & MP3 & MP4 & MP5 \\
\hline TT (cm) & 0.73 & 0.59 & 0.24 & -0.14 & 0.10 \\
PA (cm) & 0.90 & 0.84 & 0.41 & 0.77 & 0.73 \\
PK (cm) & 1.63 & 1.43 & 0.65 & 0.62 & 0.83 \\
BKT (g) & 0.0029 & 0.0042 & 0.0021 & -0.0031 & 0.0031 \\
BKA (g) & -0.0003 & 0.0040 & -0.0018 & -0.0008 & 0.0034 \\
BKK (g) & 0.0026 & 0.0082 & 0.0002 & -0.0039 & 0.0065
\end{tabular}

Keterangan: MP1 = Cocopeat $(4000 \mathrm{ppm} \mathrm{NaCl}), \mathrm{MP} 2=$ Cocopeat $(3000 \mathrm{ppm} \mathrm{NaCl}), \mathrm{MP} 3=$ arang sekam + cocopeat $(4000 \mathrm{ppm})$, MP4 $=$ arang sekam + cocopeat $(5000 \mathrm{ppm})$, MP5 $=$ Arang sekam $(9000 \mathrm{ppm}) . \mathrm{PK}=$ panjang kecambah, TT $=$ tinggi tajuk, $\mathrm{PA}=$ panjang akar, $\mathrm{BKT}=$ bobot kering tajuk, $\mathrm{BKA}=$ bobot kering akar, $\mathrm{BKK}=$ bobot kering kecambah.

Pada metode MP1 perbedaan antara varietas toleran dan peka terlihat dari selisih yang lebih besar antara kedua kelompok varietas pada peubah panjang kecambah, tinggi tajuk, dan panjang akar, namun pada seluruh peubah bobot kering MP2 terlihat memiliki perbandingan selisih yang tinggi dengan MP1 dibandingkan pada peubah tinggi tajuk, panjang akar dan panjang kecambah. Terlihat bahwa MP2 pada peubah bobot kering kecambah (BKK) memiliki selisih antara varietas toleran dan peka sebesar $(0.0082 \mathrm{~g})$ dimana nilai ini hampir 3 kali lipat dengan peubah BKK pada MP1 (0.0026).

MP4 pada peubah tinggi tajuk, bobot kering tajuk, bobot kering akar dan bobot kering kecambah terlihat memiliki selisih yang negatif (-) dimana varietas peka memiliki nilai yang lebih tinggi dari varietas toleran, sehingga MP4 tidak dapat membedakan varietas toleran dan yang peka. Menurut Pearson dalam Suwarno (1985), beberapa tanaman padi dapat hidup pada tanah dengan salinitas tinggi berdaya hantar lisrik 15 mmhos/cm (9600 ppm), tetapi pada tanah yang berdaya hantar listrik $6-7 \mathrm{mmhos} / \mathrm{cm}(3840 \mathrm{ppm}$ $-4500 \mathrm{ppm}$ ) diduga telah terjadi penurunan hasil sebesar 50 persen.

Berdasarkan hasil selisih antara varietas toleran dan peka, metode MP2 (cocopeat dengan
3000 ppm $\mathrm{NaCl}$ ) merupakan metode dengan menggunakan media padat yang lebih dapat memperlihatkan perbedaan antara varietas toleran dan peka.

Media kertas. Lima konsentrasi hasil percobaan pendahuluan dengan kertas merang yang mampu membedakan kedua sifat varietas berdasarkan hasil uji $\mathrm{t}$ dan nilai selisih diuji kembali untuk mendapatkan metode yang paling baik.

Tabel 4 menunjukkan selisih antara kelompok varietas toleran dan kelompok varietas peka. Sebagian besar peubah-peubah yang diamati pada MK1 (4000 ppm NaCl) memiliki selisih nilai antara kelompok varietas toleran dengan peka yang paling besar, yang menandakan juga bahwa pada konsentrasi tersebut terdapat perbedaan yang lebih jelas antara dua kelompok varietas dibandingkan dengan tingkat konsentrasi yang lain. Media kertas merang pada konsentrasi 4000 ppm menunjukkan varietas peka sulit beradaptasi pada kondisi salin, sehingga menekan pertumbuhan vegetatif, sedangkan varietas toleran masih mampu mengatasi faktor cekaman sehingga pertumbuhan belum mampu dihambat. 
Tabel 4. Rekapitulasi data santara varietas toleran dan peka pada masing-masing peubah yang diamati di laboratorium pada media kertas

\begin{tabular}{lccccc}
\hline & \multicolumn{5}{c}{ Selisih } \\
\cline { 2 - 6 } & MK1 & MK2 & MK3 & MK4 & MK5 \\
\hline TT $(\mathrm{cm})$ & 1.62 & 1.45 & 1.04 & 1.20 & 1.36 \\
PA $(\mathrm{cm})$ & 0.85 & 0.60 & 0.43 & 0.59 & 0.47 \\
PK $(\mathrm{cm})$ & 2.47 & 2.05 & 1.47 & 1.79 & 1.82 \\
BKT $(\mathrm{g})$ & 0.0187 & 0.0068 & 0.0058 & 0.0158 & 0.0148 \\
BKA $(\mathrm{g})$ & 0.0095 & -0.0004 & 0.0026 & 0.0057 & 0.0061 \\
BKK $(\mathrm{g})$ & 0.0282 & 0.0064 & 0.0084 & 0.0215 & 0.0208 \\
\hline
\end{tabular}

Keterangan: $\mathrm{PK}=$ panjang kecambah, TT = tinggi tajuk, $\mathrm{PA}=$ panjang akar, $\mathrm{BKT}=$ bobot kering tajuk, $\mathrm{BKA}=$ bobot kering akar, $\mathrm{BKK}=$ bobot kering kecambah, MK1 $=4000 \mathrm{ppm} \mathrm{NaCl}, \mathrm{MK} 2=5000 \mathrm{ppm} \mathrm{NaCl}, \mathrm{MK} 3=6000 \mathrm{ppm} \mathrm{NaCl}, \mathrm{MK} 4=$ $7000 \mathrm{ppm} \mathrm{NaCl}, \mathrm{MK} 5=8000 \mathrm{ppm} \mathrm{NaCl}$

MK2 pada peubah bobot kering akar terlihat varietas peka lebih berat dibandingkan dengan varietas toleran, sehingga memiliki selisih yang negatif $(-0,0004)$. Kesulitan peneliti dalam menimbang bobot kering akar adalah bentuk akar yang kecil, ringan, dan mudah hancur ketika di pisahkan dari pangkal tajuk, sehingga dibutuhkan ketelitian agar bobot akar dapat tertimbang dengan tepat.

Pengujian benih khususnya padi sangat baik bila menggunakan substrat kertas. Jatuhnya pilihan kepada kertas merang karena memiliki daya absorpsi air yang tinggi, jauh lebih sedikit ruang yang diperlukan untuk penempatan materi yang diuji. warna kertas merang yang coklat muda, polos dan tidak luntur akan memudahkan penguji dalam mengamati dan menilai kecambah yang tumbuh (sadjad, 1993). Berdasarkan selisih antara varietas toleran dengan varietas peka, metode kertas merang dengan konsentrasi 4000 ppm (MK1) merupakan satu metode terpilih. Pemakaian substrat kertas ini terbukti lebih praktis. Metode ini (MK1) selanjutnya digunakan dalam pengujian terhadap 40 genotipe padi. Dibandingkan dengan media terpilih pada media padat (MP2), MK1 memperlihatkan hasil yang mampu membedakan sifat varietas toleran dan peka pada seluruh peubah pengamatan.

\section{Pengujian Toleransi Salinitas 40 Genotipe Padi di Rumah Kaca}

Pengelompokan genotipe padi pada pengujian di rumah kaca dilakukan berdasarkan persentase daun mati seperti yang ditunjukkan pada Tabel 5.

Tabel 5. Pengelompokan genotipe pada pengujian di rumah kaca berdasarkan persentase daun mati

\begin{tabular}{ccc}
\hline No & Persentase Daun Mati (\%) & Tingkat Salinitas \\
\hline 1 & $>0-\leq 50$ & Toleran \\
2 & $>50-\leq 70$ & Agak Toleran \\
3 & $>70-\leq 90$ & Agak Peka \\
4 & $>90-\leq 100$ & Peka \\
\hline
\end{tabular}

Sumber : IRRI dalam Suhaimi (1980)

Tabel 6 menjelaskan bahwa berdasarkan tingkat persentase daun mati, genotipe-genotipe yang diuji di rumah kaca terbagi menjadi empat tingkat toleransi yaitu toleran (7 genotipe), agak toleran (19 genotipe), agak peka (14 genotipe) dan peka (4 genotipe). Suwarno (1985) menyatakan bahwa parameter yang baik untuk mengukur toleransi varietas pada cekaman salinitas adalah persentase daun yang mati atau daun yang mengering, hal ini disebutkan juga oleh Yuniati (2004) bahwa pengaruh utama salinitas adalah berkurangnya pertumbuhan daun yang langsung mengakibatkan berkurangnya fotosintesis tanaman. 
Tabel 6. Rata-rata dan kisaran nilai genotipe padi di rumah kaca berdasarkan tingkat toleransi persentase daun mati (PDM)

\begin{tabular}{ccc}
\hline Tingkat & Jumlah & Rata-rata \\
Toleransi & Genotipe & PDM $(\%)$ \\
\hline Toleran & 7 & 39.38 \\
& & $(30.03-49.08)$ \\
Agak toleran & 19 & 59.32 \\
Agak peka & & $(50.25-69.96)$ \\
& 14 & 80.83 \\
Peka & 4 & $(70.10-89.68)$ \\
& & 94.6 \\
\end{tabular}

Varietas toleran Lalan memiliki nilai persentase daun mati terendah, yaitu sebesar $30.03 \%$, diikuti oleh genotipe B11844-MR-23-46, B13133-9-MR-3-KY-2, dan B13136-3-MR-1KY-5 masing-masing sebesar $34.10 \%, 35.03 \%$,
$38.30 \%$, sedangkan varietas toleran Pokali memiliki nilai persentase daun mati lebih tinggi sebesar $68.14 \%$, varietas peka Ciherang sebesar $80.32 \%$ dan IR64 sebesar $87.60 \%$.

Tabel 7. Nilai koefisiensi korelasi antara peubah di rumah kaca

\begin{tabular}{cc}
\hline Peubah & Koefisien korelasi \\
\hline PDM vs JD & $\mathbf{- 0 . 9 1 6 * *}$ \\
PDM vs BKTa & $-0.796^{* *}$ \\
PDM vs BAK & $-0.766^{* *}$ \\
PDM vs BT & $-0.785^{* *}$ \\
PDM vs PA & $\mathbf{- 0 . 9 1 8 * *}$ \\
PDM vs TT & $-0.872^{* *}$ \\
PDM vs PT & $-0.902^{* *}$
\end{tabular}

Keterangan : PDM = persentase daun mati, JD = jumlah daun, PA = panjang akar, TT = tinggi tajuk, PT = panjang total tanaman, $\mathrm{BKTa}=$ bobot kering tanaman, $\mathrm{BAK}=$ bobot kering akar, $\mathrm{BT}=$ bobot kering tajuk, $\mathrm{tn}=$ tidak berbeda nyata, $* *=$ berbeda nyata pada taraf $1 \%$.

Varietas pokali yang biasa digunakan dalam seleksi pada cekaman salinitas sebagai cek toleran terlihat memiliki persentase daun mati yang cukup tinggi dan berada pada tingkat agak toleran, hal ini mungkin disebabkan oleh vigor benih Pokali yang menurun.

Tabel 7 menyajikan korelasi antara persentase daun mati dengan peubah-peubah lain yang diamati di rumah kaca. Korelasi ini untuk melihat suatu peubah yang dapat menggambarkan suatu parameter lain untuk seleksi cekaman salinitas selain peubah persentase daun mati. Korelasi antara peubah persentase daun mati dengan panjang akar memiliki nilai yang berbeda nyata dan menghasilkan nilai koefisien korelasi paling tinggi (-0.918), secara sederhana nilai korelasi ini menjelaskan bahwa selain persentase daun mati, peubah panjang akar juga dapat digunakan untuk menilai tingkat toleransi pada cekaman salinitas di rumah kaca. Nilai yang negatif menunjukkan bahwa semakin besar persentase daun mati maka panjang akar akan semakin rendah.

Sipayung (2006) menyatakan bahwa salinitas tanah akan menghambat pembentukan akar-akar baru dan akar tanaman mengalami kesukaran dalam menyerap air karena tingginya tekanan osmosis larutan tanah, keadaan ini selanjutnya akan menyebabkan terjadinya situasi seperti kekeringan pada tanaman. Teori lain dijelaskan oleh Sari et al., (2006), akumulasi ion $\mathrm{Cl}^{-}$cenderung menurunkan penyerapan phospor yang berperan penting dalam menggerakan dan menyimpan energi serta perkembangan akar. Defisiensi phosphor menyebabkan perkembangan akar tanaman terhambat sehingga akar yang terbentuk jumlahnya sedikit. Oleh karena itu, nilai koefisien korelasi panjang akar dikatakan sangat kuat untuk menggambarkan kondisi persentase daun mati di rumah kaca. 


\section{Korelasi antara Peubah di Rumah Kaca dengan Peubah di Laboratorium}

Tabel 8. Korelasi antara peubah pengujian di rumah kaca dengan pengujian di laboratorium

\begin{tabular}{cccc}
\hline \multirow{2}{*}{ Laboratorium } & \multicolumn{3}{c}{ Rumah kaca } \\
\cline { 2 - 4 } & JD & PDM & PA \\
\hline TT & $0.2269^{\text {tn }}$ & $-0.2766^{\text {tn }}$ & $0.2642^{\text {tn }}$ \\
PA & $0.0682^{\text {tn }}$ & $-0.1168^{\text {tn }}$ & $0.1272^{\text {tn }}$ \\
PK & $0.2138^{\text {tn }}$ & $-0.2697^{\text {tn }}$ & $0.2616^{\text {tn }}$ \\
BKT & $0.2972^{\text {tn }}$ & $-\mathbf{0 . 3 0 7 1}$ & $0.2324^{\text {tn }}$ \\
BKA & $-0.0195^{\text {tn }}$ & $0.0128^{\text {tn }}$ & $-0.0822^{\text {tn }}$ \\
BKK & $0.2328^{\text {tn }}$ & $-0.2424^{\text {tn }}$ & $0.1654^{\text {tn }}$
\end{tabular}

Keterangan : PDM = persentase daun mati, TT = Tinggi tajuk, PK = panjang kecambah, PA = panjang akar, BKT = bobot kering tajuk, BKA = bobot kering akar, BKK $=$ Bobot kering kecambah, JD = jumlah daun, $*=$ berbeda nyata pada taraf $5 \%$, $* *$ = berbeda nyata pada taraf $1 \%$, tn $=$ tidak berbeda nyata.

Korelasi antara persentase daun mati di rumah kaca dengan peubah yang diamati di laboratorium dilakukan untuk mengetahui peubah di laboratorium yang dapat menggambarkan persentase daun mati di rumah kaca. Tabel 8 menunjukkan pada peubah persentase daun mati di rumah kaca terlihat berhubungan secara signifikan hanya pada peubah bobot kering tajuk di laboratorium. Korelasi yang lemah dan tidak nyata menunjukkan bahwa peubah di laboratorium pada satu metode terpilih tidak dapat secara jelas menggambarkan persentase daun mati di rumah kaca atau memiliki keeratan yang sangat lemah antara dua peubah tersebut. Hal ini mungkin disebabkan karena waktu stadia pertumbuhan yang berbeda antara pengujian di rumah kaca dan di laboratorium. Menurut Rahmawati (2006) padi relatif lebih toleran terhadap salinitas saat perkecambahan, akan tetapi tanaman bisa jadi rentan saat pindah tanam, bibit masih muda, dan pembungaan, sehingga agak sulit menentukan hubungan antara toleransi terhadap salinitas pada fase perkecambahan dengan fase-fase berikutnya.

Hubungan yang paling kuat ditunjukkan pada korelasi antara persentase daun mati (PDM) di rumah kaca dengan bobot kering tajuk (BKT) di laboratorium (-0.3071). Sari et al., (2006) menjelaskan secara fisiologis hubungan antara PDM dan BKT dimana daun sangat dibutuhkan sebagai dapur dalam proses fotosintesis yang akan menghasilkan senyawa organik untuk pertumbuhan tanaman. Penurunan jumlah daun pada perlakuan $\mathrm{NaCl}$ diakibatkan penurunan kemampuan tanaman untuk mengabsorbsi air sehingga jumlah air sel tanaman semakin berkurang yang menyebabkan turgor sel-sel penutup stomata turun. Penurunan turgor stomata akan memotong suplai $\mathrm{CO}_{2}$ ke sel-sel mesofil dan mengakibatkan proses fotosintesis terhambat sehingga jumlah asimilat yang dihasilkan oleh tanaman semakin berkurang. Hal inilah yang menyebabkan bobot kering tajuk tanaman padi semakin berkurang. Untuk menilai toleransi genotipe padi terhadap salinitas di laboratorium selanjutnya digunakan peubah bobot kering tajuk.

\section{Pengujian 40 Genotipe Padi pada Satu metode Terpilih di Laboratorium}

Pengujian genotipe dengan satu metode terpilih di laboratorium menggunakan kertas merang dengan konsentrasi 4000 ppm. Analisis ragam menunjukkan bahwa genotipe-genotipe yang diuji di laboratorium menghasilkan nilai yang berbeda nyata pada seluruh peubah kecuali peubah panjang akar. Hasil yang berbeda nyata ini menunjukkan bahwa antara genotipe yang diuji memiliki beberapa perbedaan karakter yang merupakan respon dari cekaman salinitas.

Hasil pengujian 40 genotipe-genotipe yang diuji, berdasarkan peubah bobot kering tajuk, nilai rata-rata dari pengujian pada satu metode terpilih sebesar $0.0770 \mathrm{~g}$ dengan nilai kisaran 0.0142 sampai $0.1278 \mathrm{~g}$ (Tabel 9). Genotipe yang memiliki bobot kering tajuk terbesar adalah B11016D-KN-2-1, B13146-1MR-1-KY-1, dan B13138-3-MR-1-KY-3. Bobot rata-rata berturut-turut sebesar $0.1073,0.1034$, $0.1032 \mathrm{~g}$. 
Tabel 9. Rata-rata dan kisaran nilai peubah yang diamati dalam pengujian 40 genotipe pada satu metode terpilih

\begin{tabular}{lrr}
\hline \multicolumn{1}{c}{ Peubah } & Rata-rata & Kisaran Nilai \\
\hline Panjang kecambah $(\mathrm{cm})$ & 19.97 & $14.83-25.80$ \\
Tinggi Tajuk $(\mathrm{cm})$ & 10.31 & $6.80-15.87$ \\
Panjang akar(cm) & 9.66 & $7.30-12.35$ \\
Bobot kering kecambah $(\mathrm{g})$ & 0.0998 & $0.0284-0.1668$ \\
Bobot kering tajuk $(\mathrm{g})$ & 0.0770 & $0.0142-0.1278$ \\
Bobot kering akar $(\mathrm{g})$ & 0.0228 & $0.0094-0.0504$ \\
\hline
\end{tabular}

\section{Simulasi Seleksi Padi Toleran Salinitas}

Simulasi seleksi ini bertujuan untuk membandingkan padi yang toleran di pengujian rumah kaca dengan padi toleran di laboratorium, dengan harapan tanaman yang dipilih akan memberikan hasil yang lebih baik. Simulasi seleksi dilakukan dengan cara mengurutkan nilai peubah bobot kering tajuk di laboratorium dari nilai terbesar hingga terkecil, sedangkan peubah persentase daun mati di rumah kaca diurutkan dari nilai terkecil hingga terbesar. Penggunaan peubah bobot kering tajuk pada simulasi seleksi dikarenakan memiliki nilai koefisien korelasi paling baik dengan persentase daun mati di rumah kaca. Genotipe padi pada peubah bobot kering tajuk di laboratorium disesuaikan dengan persentase daun mati di rumah kaca berdasarkan intensitas seleksi yang digunakan.

Tabel 10. Simulasi seleksi hasil pengujian di rumah kaca dan laboratorium

\begin{tabular}{cccc}
\hline $\begin{array}{c}\text { Intensitas } \\
\text { Seleksi (\%) }\end{array}$ & $\begin{array}{c}\text { Jumlah } \\
\text { Genotipe } \\
\text { yang terpilih }\end{array}$ & $\begin{array}{c}\text { Jumlah genotipe } \\
\text { yang sesuai }\end{array}$ & $\begin{array}{c}\text { Kesusaian } \\
(\%)\end{array}$ \\
\hline 10 & 4 & PDM $^{\text {a) }}$ vs BKT $^{\text {b) }}$ & 0 \\
20 & 8 & 0 & 12.50 \\
30 & 12 & 1 & 25.00 \\
40 & 16 & 3 & 37.50 \\
45 & 18 & 6 & 50.00 \\
50 & 20 & 9 & 55.00 \\
\hline
\end{tabular}

Keterangan : a) = peubah rumah kaca, b) = peubah laboratorium, PDM = persentase daun mati, BKT = Bobot Kering Tajuk

Pada Tabel 10, jumlah genotipe yang sesuai antara kedua peubah menunjukkan kemampuan pengujian di laboratorium yang dapat menggambarkan hasil pengujian di rumah kaca. Hasil simulasi seleksi pada tabel 10 menunjukkan bahwa penggunaan metode kertas merang dengan konsentrasi 4000 ppm akan efektif apabila menggunakan intensitas seleksi diatas $45 \%$, yang akan menghasilkan kesesuaian paling tidak sebesar $50 \%$.

Nilai intensitas seleksi yang semakin besar pada kedua peubah yang disimulasiseleksikan menunjukkan bahwa peubah di laboratorium kurang dapat menggambarkan kondisi persentase daun mati di rumah kaca secara akurat dalam menyeleksi genotipe padi yang tahan salinitas. Simulasi seleksi ini akan lebih efektif digunakan dalam seleksi tahap awal pengujian genotipe.

\section{KESIMPULAN}

Percobaan awal di laboratorium menghasilkan lima metode media padat dan lima metode di media kertas yang dapat memperlihatkan perbedaan antara varietas yang toleran dan varietas yang peka. Metode tersebut adalah media arang sekam (9000 ppm $\mathrm{NaCl})$, arang sekam + cocopeat (4000 dan 5000 ppm $\mathrm{NaCl})$, serta cocopeat (3000 dan $4000 \mathrm{ppm} \mathrm{NaCl})$. 
Sementara untuk media kertas merang yang dinilai berpotensi adalah konsentrasi $\mathrm{NaCl} 4000$, 5000, 6000, 7000 dan 8000 ppm. Metode menggunakan kertas merang dengan konsentrasi $\mathrm{NaCl} 4000$ ppm merupakan satu metode terpilih yang digunakan dalam pengujian 40 genotipe pada skala laboratorium.

Pengujian di Rumah Kaca berdasarkan indikator persentase daun mati menunjukkan bahwa dari 40 genotipe dan 2 varietas toleran dan peka yang diuji, 7 genotipe berada pada tingkat toleran, 19 genotipe agak toleran, 14 genotipe agak peka dan 4 genotipe peka. Varietas toleran Lalan memiliki nilai persentase daun mati terendah, yaitu sebesar $30.03 \%$, diikuti oleh genotipe B11844-MR-23-4-6 (34.10 \%), B131339-MR-3-KY-2 (35.03\%), dan B13136-3 -MR-1KY-5 $(38.30 \%)$.

Korelasi antara peubah di rumah kaca dengan peubah di laboratorium tidak menunjukkan korelasi yang kuat, peubah persentase daun mati di rumah kaca mempunyai nilai koefisien korelasi terbesar ( -0.3071) dan berbeda nyata dengan peubah bobot kering tajuk di laboratorium. Simulasi seleksi tahap awal di laboratorium dengan menggunaan metode kertas merang $4000 \mathrm{ppm} \mathrm{NaCl}$ hanya menghasilkan kesesuaian sebesar 50\% pada intensitas seleksi 45 $\%$ pada peubah bobot kering tajuk.

\section{DAFTAR PUSTAKA}

DPU. 1997. Kebijaksanaan Pembangunan Irigasi dalam Peningkatan Produksi Pangan [Internet]. [diunduh 2011 Januari 24]. Tersedia pada : http://binamarga.pu.go.id.

Pratama, G.S. 2010. Analisis respon toleransi padi Nipponbare transgenik terhadap salinitas tinggi. [skripsi]. Bogor (ID) : Institut Pertanian Bogor.

Rahmawati. 2006. Status perkembangan dan perbaikan genetik padi menggunakan teknik transformasi Agrobacterium. Agrobiogen 2 : 364-375.

Sadjad, S. 1993. Dari Benih Kepada Benih. Jakarta (ID) : Gransindo.

Sari, H.C., Darmanti, S., Hastuti. E.D. 2006. Pertumbuhan tanaman jahe emprit (Zingiber officinale Var. Rubrum) pada media tanam pasir dengan salinitas yang berbeda. Buletin Anatomi dan Fisiologi 14 (2): 19-29.

Sipayung, R. 2006. Stres garam dan mekanisme toleransi tanaman. J. Hayati 5:18-20.

Sulaiman, S. 1980. penyaringan varietas padi sawah bagi penyesuaian terhadap tanah berkadar garam tinggi. [disertasi]. Bogor (ID) : Institut Pertanian Bogor.

Suwarno. 1985. Pewarisan dan fisiologi sifat toleran terhadap salinitas pada tanaman padi. [disertasi]. Bogor (ID) : Institut Pertanian Bogor. 